\title{
An Inter-Block Level Analysis of Regional Disparity in the Youngest Alipurduar District of West Bengal
}

Koyel Sam ${ }^{\dagger}$ and Dr. Namita Chakma'

\begin{abstract}
Alipurduar (also known as 'Dooars') was a subdivision of Jalpaiguri district before its emergence as the new 20th district of West Bengal on 25 June 2014. The districts of North Bengal (including Darjeeling, Jalpaiguri, Coochbehar, Uttar Dinajpur, Dakshin Dinajpur and Malda) have been poorly placed in comparison to the state of West Bengal, in terms of Human Development Indicators: low literacy level, poor condition in sanitation, and partly availability of electricity and safe drinking water (Report on Comparative Backwardness of North Bengal Region, Government of India, 2002). Research on regional disparity is essential for addressing the lacuna in the planning process of development (Sen, 2001). In the present study, an analysis has been made in terms of the interblock inequality in socio-economic and infrastructural development of Alipurduar district as a newly emerged region.
\end{abstract}

Key words: Dooars, North Bengal, Human Development, regional disparity, inter-block inequality.

\footnotetext{
${ }^{+}$Research Scholar (UGC-JRF), Department of Geography, The University of Burdwan, Barddhaman, India Email: koyelsam04@gmail.com

ì Assistant Professor, Department of Geography, The University of Burdwan, Barddhaman, India Email: namitachakma@gmail.com

C2016 Sam and Chakma. This is an Open Access article distributed under the terms of the Creative Commons Attribution License (http://creativecommons.org/licenses/by/2.0), which permits unrestricted use, distribution, and reproduction in any medium, provided the original work is properly cited.
} 


\section{Introduction}

Inter-regional disparity has been an integral feature of the history of India's socio-economic development. The magnitude of regional disparity became wide during the British colonial period. Few regions around the port cities of Mumbai (Bombay), Kolkata (Calcutta), and Chennai (Madras) were developed for their own business interest. After independence in 1947, a considerable emphasis was given to eliminate this problem. In the third five year plan (196166), a separate chapter (Chapter IX) was devoted to balance regional development. National Committee on Development of Backward Areas (NCDBA) had recommended policies at the centre and state level. This committee suggested block-level development to be the criterion for assessing backwardness. Pandey Committee $^{1}$ and Chakraborty Committee ${ }^{2}$ were constituted for identification of backward areas and to suggest strategies to minimise regional imbalance (Kumar, 2009). Despite multiple efforts being undertaken, India has still been experiencing a wide inter- as well as intraregional disparities, both at macro and micro level in socio-economic and infrastructural development.

Disparity is an expression of the condition and facts of a certain phenomenon which is being unequal or dissimilar within and among the regions. Disparity is divergence or inequality of characters, phenomena or processes, the identification and comparison of which make some rational sense, that is, cognitive, psychological, social, economic, political, etc. (Kutscherauer et al., 2010). In contemporary literature, regional disparity has been studied in many different ways. The literature on regional disparity, therefore, is also vast and varied. Most studies have targeted State as the unit for measuring disparity. A good number of writings and research papers have already been carried out to identify disparity at state level using different methods and indicators. The study on

\footnotetext{
${ }^{1}$ This committee was appointed in 1968. An attempt was made to identify backward area and a package of incentives provide in such areas were seriously considered.
}

inter-state disparities in terms of economic and infrastructural indicators has been discussed in the works of Das and Barua (1996), Ahluwalia (2000, 2001), Shaban (2002), Chandrasekhar and Ghosh (2003), Shetty (2003) and Chandrasekhar (2011).

Dadabhavi and Bagalkoti (1994) in their study explained disparities in terms of health indicators. Chakraborty (2009) has analysed the aspects of disparity in non-income dimensions. He gave emphasis on distribution of primary school infrastructure across and within states of India. Drèze and Sen (1995) have pointed out that the social variables are also important for the achievement of the desired economic growth and path of development. Raj (1990) has analysed the importance of bridging rural-urban gap in India. On the other hand, trends of poverty unemployment and public intervention in India have been elaborated by Radhakrishna and Rao (2006).

In 1965, Mitra (1965) first attempted to highlight the regional disparity by using district level data. Mitra's study on 'Level of Regional Development in India' was based on a simple method of 'assigning and adding up ranks' based on 1961 Census data. Shastri (1988) has examined the regional disparity of Rajasthan which covers a period of 23 years (1961-1984). Shaban (2006) has examined the regional disparity of Maharashtra by using Principal Component Analysis (PCA) technique.

There exists dearth of literature on inter-block level disparity in West Bengal. As the chosen study area is the youngest district in the state (since June, 2014) therefore, no such systematic work has done before on inter-block level disparity of the district. For this, an attempt has been made here to highlight the inter-block level disparity in terms of socio-economic and infrastructural development indicators of the district. The analytical work is structured into two parts: the first part deals with evaluating the

\footnotetext{
${ }^{2}$ This committee was constituted under the chairmanship of Professor Sukhmay Chakraborty in 1972. The committee had suggested district as an unit for formulation and implementation of plans.
} 
level of absolute disparity on the basis of social, economic and infrastructural indicators, and the second part deals with examining the relative position of the individual blocks within the district in terms of level of development.

\section{The Study Area}

Alipurduar (also known as 'Dooars') was a subdivision of Jalpaiguri district before its emergence as the new $20^{\text {th }}$ district of West Bengal on 25 June 2014. ${ }^{3}$ The district Jalpaiguri was originally named Baikunthapur and was established in the year 1869 (Gruning, 1911). Before reorganising the district boundary, Jalpaiguri was one of the largest districts in West Bengal and backward too according to a Report on Comparative Backwardness of North Bengal Region (2002). The people of Alipurduar subdivision had faced hardships in receiving government services and had to spend long hours travelling $100 \mathrm{kms}$ to reach the district headquarter. After long standing demand of the people in Alipurduar subdivision, the new Alipurduar district was created, constituting Alipurduar municipality. The district now contains nine Census towns, 66 gram panchayats under six community development blocks namely, Madarihat-Birpara, AlipurduarI, Alipurduar-II, Falakata, Kalchini and Kumargram. The district had a population of 73,047 in 2001 and in 2011, the total population increased to $127,342 .{ }^{4}$ The district covers 3383 sq. $\mathrm{km}$ area and extents from $26024^{\prime} \mathrm{N}$ to 260 $51^{\prime} \mathrm{N}$ and from 89 2' $\mathrm{E}$ to 89 53' $\mathrm{E}$ (see Figure 1).

This strategic location of Alipurduar district is quite important so far as the defence, development and economy of the region are concerned. The long international broder with the neighbouring country of Bhutan has shared $105 \mathrm{~km}$ length in north. Buxa in Kalchini block of the district acts as corridor for international trade between India and Bhutan. Since time immemorial, wool, ivory, wax, silk cloth, and piece-goods are being imported from Bhutan,

\footnotetext{
${ }^{3}$ Alipurduar a new district on June 25 (2014, 21 June, The Times of India). Retrieved from: http://timesofindia.indiatimes.com/city/kolkata/Alipurdu ar-a-new-district-on-June-25/articleshow/36916065.cms
}

Tibet and Central Asia through this route. The principal exports are tea, jute, tobacco, vegetable, rice and timber, etc. (Gruning, 1911). Therefore, if development plans are executed properly, the region has a good chance to regain its prosperity.

\section{Objectives}

The objectives of the present work are as follows:

- To find out the inter-block level absolute disparity on the basis of social, economic and infrastructural indicators within the district; and

- To evaluate the relative position of the individual blocks in terms of level of development within the district.

\section{Materials and Methods}

For this research, data had been collected from secondary sources - District Census Report, 2011, (http://censusindia.gov.in) and District Statistical Handbook, Jalpaiguri, 2008.

Researchers generally used several statistical techniques for studying inter and intra-regional disparity on the basis of some indicators. Each and every method of measuring of a parameter has its own merits and limitations. We have used two methods of measuring development disparities among the blocks of Alipurduar district. Deprivation method is an absolute measure, and it throws light on the degree of deprivation and development. In Human Development Report published by United Nations Development Programme (UNDP), Human Development Index (HDI) has been calculated by using this technique (Shive, 1991). Principal Component Analysis (PCA) is a relative measure, it helps to identify dominant and subordinate factors as well as classifies region in different scales. Here, PCA is applied to identify relatively developed and backward blocks of Alipurduar district.

4 The total population of Alipurduar district is 127342 (Census of India, 2011). Retrieved from: http://www.alipurduar.org/ 


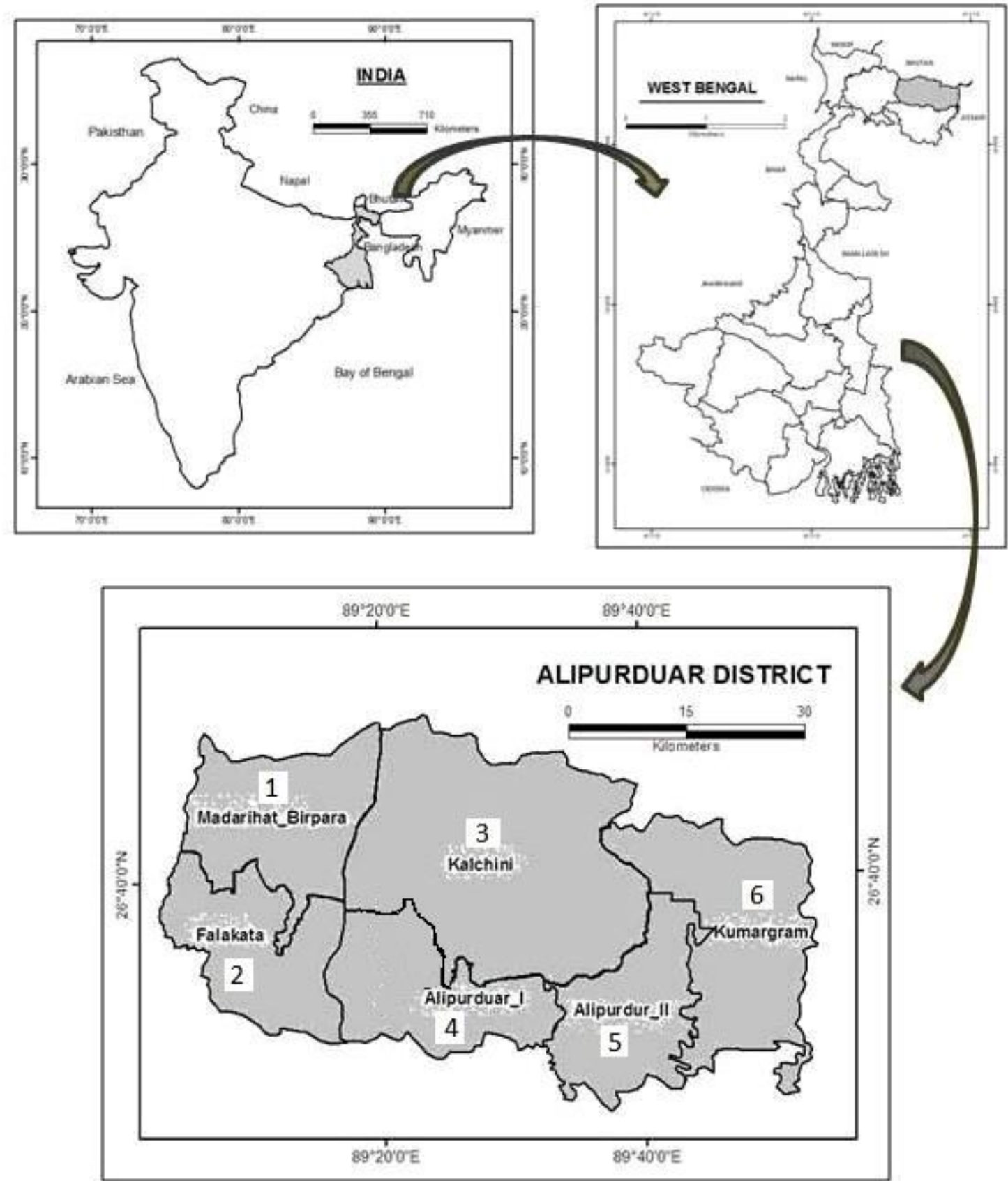

Figure 1: Location Map of the District (Source: Authors)

1. Deprivation Method: The deprivation indicator lij for the $j$ th district $(j=1,2,3, \ldots \ldots .6)$ with respect to the ith indicator $(i=1,2,3, \ldots \ldots .18)$ is given by

$$
\text { Iij (Dimension Index })=\frac{\text { Actual Value }- \text { Minimum Value }}{\text { Maximum Value }- \text { Minimum Value }}
$$

2. Principal Component Analysis: This method of analysis was first proposed by Karl Pearson (1927) as factor analysis and fully developed as the method of Principal Component Analysis by Harold Hotelling. The model for Component analysis is simply:

$Z_{j}=a_{j 1} X_{1}+a_{j 2} X_{2}+\ldots \ldots \ldots \ldots+a_{j n} X_{n} \quad(X=1,2,3 \ldots n)$ 
Where, $\mathrm{Z} \mathrm{j}$ is called principal components which are linear combination of the $X^{\prime}$ 's and $a_{j n}$ 's are called 'loading'. For a practical problem only few variables may be retained, especially if they reflect a large percentage of the total variance (see Result and Discussion-PCA section for detail analysis).

\section{Results and Discussion}

In the present study, deprivation method has been used to identify the absolute level of disparity in terms of social, economic and infrastructural (transport and communication,

health and education) development. On the basis of these aforesaid categories, the indicators are taken into consideration for the analysis (see Table 1; Figures 2, $3 \& 4$ ).

The value of developmental index ranges from ' 0 ' to ' 1 '. Lowest value of individual indicator denotes' 0 ' and the highest value indicates ' 1 '. Table 2 illustrates the dimension indices using Deprivation method. Then category wise 'Index of Development' has been noted by calculating composite dimension value.

Table 1: List of Indicators to Measure Inter Block Level Disparity of Alipurduar District

\begin{tabular}{|c|c|c|}
\hline \multicolumn{2}{|c|}{ Category } & Indicators \\
\hline \multicolumn{2}{|c|}{ 1. Social Condition } & $\mathrm{X}_{1} \cdot$ Sex ratio \\
\hline \multicolumn{2}{|c|}{ 2. Economic Condition } & $\mathrm{X}_{3}$. Percentage of workers \\
\hline \multirow{3}{*}{$\begin{array}{l}\text { 3.Infrastructural } \\
\text { Condition }\end{array}$} & $\begin{array}{l}\text { a. Transport and } \\
\text { Communication }\end{array}$ & $\begin{array}{l}\mathrm{X}_{5} \text {. Road density/per sq } \mathrm{km} \\
\mathrm{X}_{6} \text {. No. of Rail Stations/per sq km } \\
\mathrm{X}_{7} \text {. Availability of internet facilities/ } \\
\text { per household }\end{array}$ \\
\hline & $\begin{array}{l}\text { b. Education } \\
\text { Facilities (per } 1000 \\
\text { population) }\end{array}$ & $\begin{array}{l}\mathrm{X}_{8} . \text { No. of Pre-Primary Schools } \\
\mathrm{X}_{9} . \text { No. of Primary Schools } \\
\mathrm{X}_{10} \text {. No. of Middle Schools } \\
\mathrm{X}_{11} \text {. No. of Secondary Schools } \\
\mathrm{X}_{12} . \text { No. of Higher secondary Schools } \\
\mathrm{X}_{13} \text {. No. of colleges } \\
\mathrm{X}_{14} \cdot \text { Others institutions }\end{array}$ \\
\hline & $\begin{array}{l}\text { c. Health Facilities (per } \\
1000 \text { population) }\end{array}$ & $\begin{array}{l}\mathrm{X}_{15} \text {. No. of Primary sub-centers } \\
\mathrm{X}_{16} \text {. No. of Doctor strengths } \\
\mathrm{X}_{17} \text {. No. of Pra-medical Staff strengths } \\
\mathrm{X}_{18} \text {. No. of beds }\end{array}$ \\
\hline
\end{tabular}

Sources: District Census Report, 2011 and Statistical Handbook, Jalpaiguri, 2008

\section{Social Condition}

Realising the importance of social condition in development, the two major indicators taken for the analysis are sex ratio $\left(X_{1}\right)$ and literacy rate $\left(X_{2}\right)$. According to 2011 Census Report, literacy rate in West Bengal is $77.08 \%$ which is more than the national average. Whereas, the literacy rate of Alipurduar, the 'youngest' district of West Bengal is $63.71 \%$, which is lower than the state average. Sex ratio of the district is same as with the state average (947). However, to study 
the inter-block disparity of social condition, combined index value has been calculated. Alipurduar-I and Alipurduar-II have shown good social condition and secure 1- 0.451 index value and comparatively moderate condition has found in Falakata and Kalchini blocks (0.4510.39). Poor sex ratio and literacy rates have been observed in Madarihat-Birpara and Kumargram blocks and are denoted by low index value 0 0.39 (see, Table 2 \& Figure 2).

Table 2: Dimension Indices, Alipurduar District

\begin{tabular}{|c|c|c|c|c|c|c|c|c|c|c|c|c|c|c|c|c|c|c|}
\hline \multirow{2}{*}{ Bariables } & \multicolumn{2}{|c|}{$\begin{array}{c}\text { Social } \\
\text { Condition }\end{array}$} & \multicolumn{2}{|c|}{$\begin{array}{l}\text { Economic } \\
\text { Condition }\end{array}$} & \multicolumn{3}{|c|}{$\begin{array}{l}\text { Transport and } \\
\text { Communication }\end{array}$} & \multicolumn{7}{|c|}{ Education Facility } & \multicolumn{4}{|c|}{ Health Facility } \\
\hline & $x_{1}$ & $x_{2}$ & $x_{3}$ & $\mathrm{X}_{4}$ & $\mathrm{X}_{6}$ & $x_{7}$ & $x_{5}$ & $x_{s}$ & $x_{9}$ & $X_{10}$ & $x_{11}$ & $X_{12}$ & $X_{13}$ & $X_{14}$ & $X_{15}$ & $X_{16}$ & $x_{17}$ & $X_{18}$ \\
\hline $\begin{array}{c}\text { Madarihat- } \\
\text { Birpara }\end{array}$ & 1 & 0 & 0.092 & 0.226 & 0.401 & 0.371 & 0 & 0.287 & 0.282 & 0.937 & 1 & 1 & 0.272 & 0 & 0.521 & 0.068 & 0 & 0.96 \\
\hline Falakata & 0 & 0.171 & 1 & 0.595 & 0 & 0 & 0.023 & 0.148 & 0.13 & 0.13 & 0.021 & 0.139 & 0.015 & 0.486 & 0.913 & 1 & 1 & 0.249 \\
\hline Kalchini & 0.29 & 0.523 & 0.048 & 0.5 & 0.375 & 0.256 & 0.443 & 0 & 0 & 0.006 & 0 & 0 & 0 & 0.169 & 1 & 0.62 & 0.575 & 0.71 \\
\hline Alipurduar-1 & 0.323 & 1 & 0.131 & 1 & 1 & 1 & 1 & 0.219 & 1 & 0 & 0.45 & 0.475 & 1 & 1 & 0 & 0.827 & 0.163 & 1 \\
\hline Alipurduar-II & 0.22 & 0.931 & 0.042 & 0 & 0.616 & 0.513 & 0.148 & 1 & 0.174 & 0.541 & 0.653 & 0.715 & 0.209 & 0.93 & 0.608 & 0 & 0.26 & 0 \\
\hline Kumargram & 0.247 & 0.487 & 0 & 0.273 & 0.544 & 0.514 & 0.182 & 0.774 & 0.713 & 1 & 0.714 & 0.118 & 0.282 & 0.522 & 0.739 & 0.62 & 0.29 & 0.461 \\
\hline
\end{tabular}

\section{Source: Prepared based on Authors' Calculation}

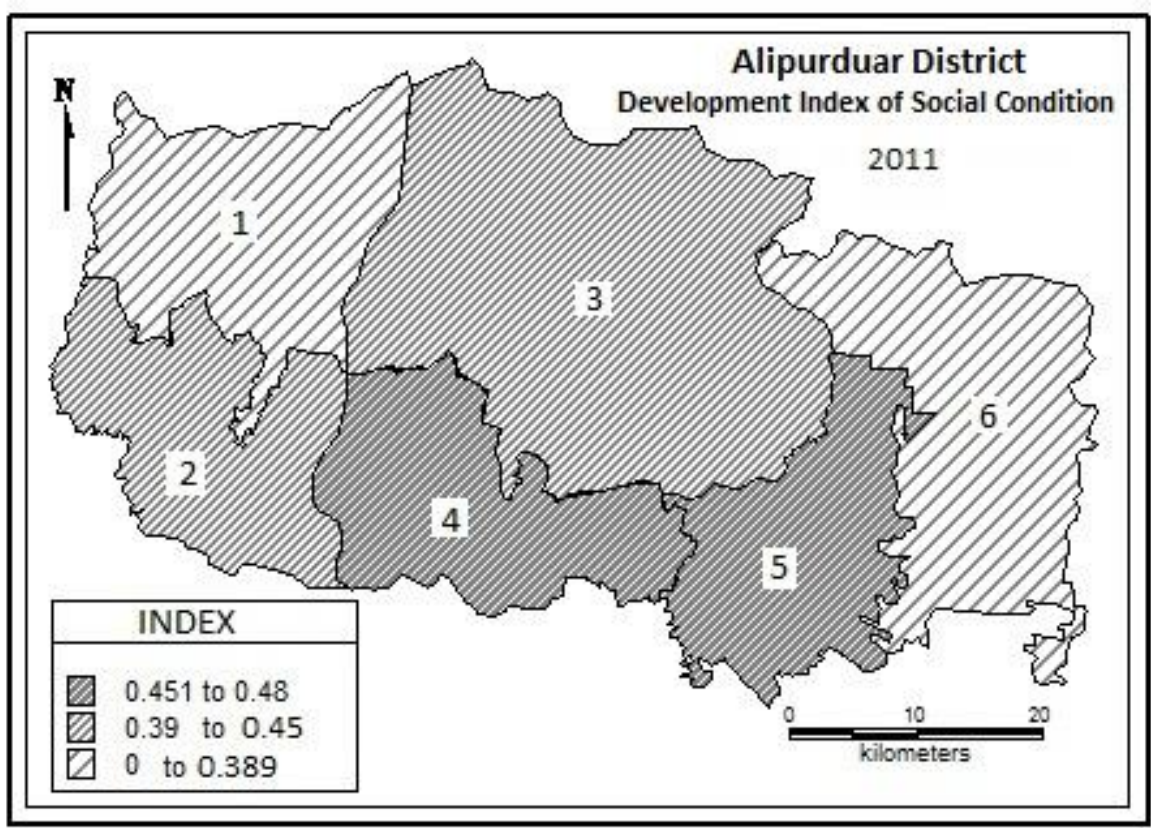

Figure 2 (Source: Authors' Calculation)

\section{Economic Condition}

Economic condition has been calculated by considering the indicators of percentage of workers $\left(X_{3}\right)$ and availability of assets $\left(X_{4}\right)$. The percentage of working population in Alipurduar district is 38 , which is slightly less than the state average (39\%). Falakata block has secured ' 1 ' index value for variable $X_{3}$ and indicates that this block is closer to the district average. In terms of availability of assets, Alipurduar- $I$ is far away from district average and scored ' 0 ' index value (see Table 2). Composite index value shows high economic condition in Kalchini and Alipurduar-I. 
This is largely due to large number of people working in tea garden and other tertiary sectors as well as availability of assets. On the other hand, Alipurduar-II has experienced poor economic condition (0-0.136). Moderate economic condition followed by in MadarihatBirpara, Kumargram and Falakata blocks are primarily due to lack of employment opportunities and assets (see Figure 3).

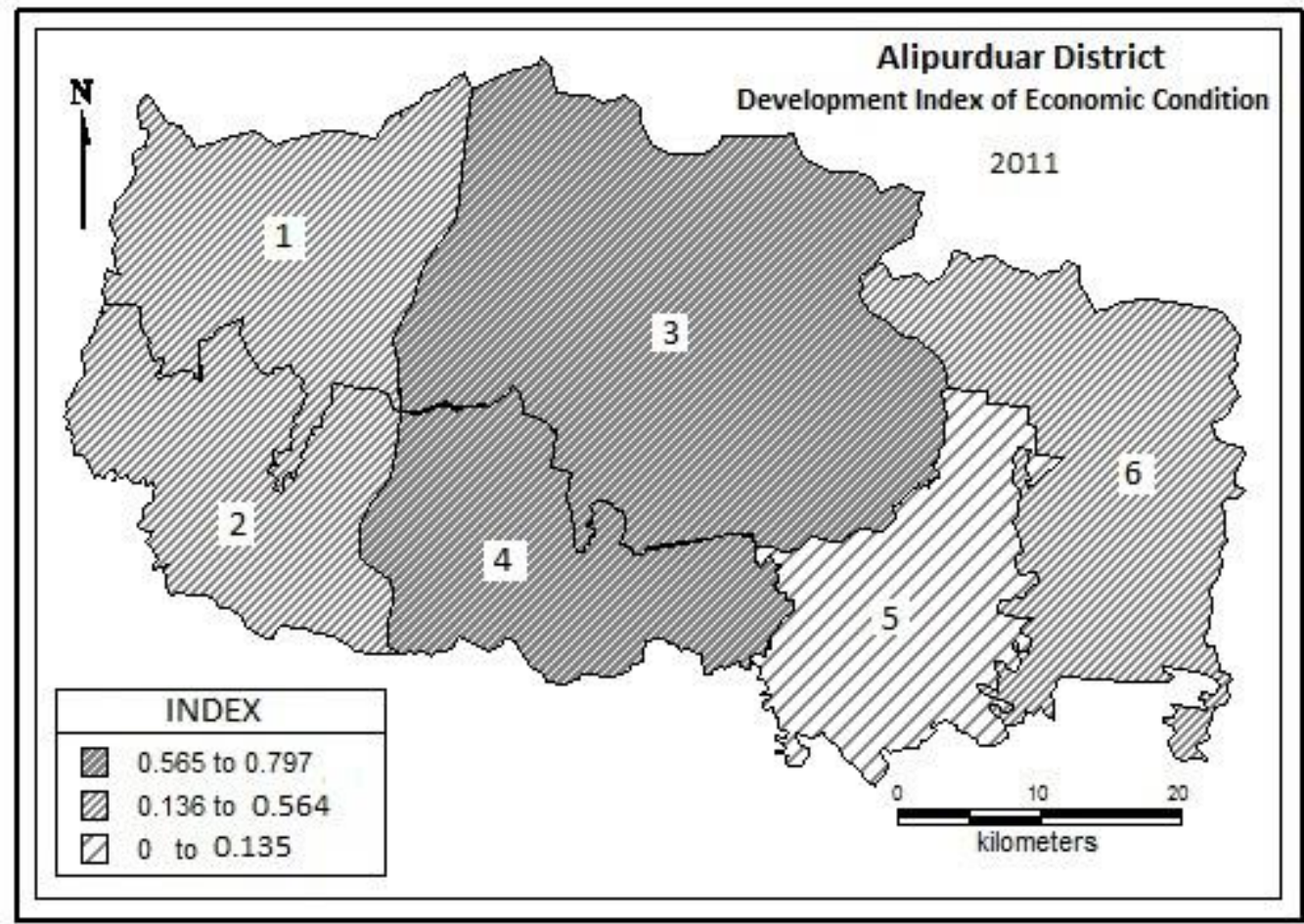

Figure 3 (Source: Authors' Calculation)

\section{Infrastructure}

Infrastructure plays a crucial role in the economic progress of a state or a region. Infrastructural services like power, transport, health facilities, education facilities, roads and railways, bank and postal services, telecommunication, etc. raise quality of life and welfare of the people. One of the major challenges faced by most of the developing region is to provide proper infrastructural services (Adhyapok and Ahmed, 2012). In the present study, infrastructural condition has been determined on the basis of three indicators: transport and communication, education and health facility. Table 2 illustrates the individual dimension index of infrastructural condition. Due to the large extent of forest cover in Madarihat-Birpara, Kalchini and Kumargram blocks, the level of transport and communication is quite poor.

Education facility is one of the significant determinants of social well-being, welfare as well as human development. Alipurduar-I and Alipurduar-II have facilitated better education infrastructure (see, Table 2).

The provision of availability of health services can ensure better health condition of its inhabitants. It is another important indicator of human development. Except for Falakata and Kumargram, health facilities are not at all satisfactory. Figure 4 shows disparity in overall infrastructural condition in Alipurduar district. The less developed blocks are identified as Alipurduar-II, Falakata, Kumargram, Kalchini and Madarihat-Birpara.

Principal Component Analysis (PCA): Principal Component Analysis (PCA) is an important method as far as summarisation of data is concerned so that each component, in turn, makes interrelatedness of the events. For a practical problem only a few components may be retained, especially if they reflect a large percentage of the total variance. A principal component analysis dealing with the correlation 
matrix of the variables is generally known as the $\mathrm{R}$-mode analysis or $\mathrm{R}$ - technique while the component analysis dwelling on the transpose of the same data matrix is labelled as Q-mode analysis or Q-technique.

Q-Mode analysis: For Q-mode analysis of function, all these eighteen variables have been loaded differently. The score in data matrix shows condition of individual variable in respect to six blocks. Considering the initial result in PC1, except for $\mathrm{X}_{6}, \mathrm{X}_{10}, \mathrm{X}_{15}$, and $\mathrm{X}_{17}$, all other variables have shown positive relationships. In that context, number of rail stations, middle schools, primary sub-centres and para-medical staff strengths are required to further development, while the percentage of workers and availability of assets are quite satisfactory containing towards loading. In the second Principal Component Analysis (PC2), sex ratio (0.625), number of middle schools (0.617) and secondary schools (0.587) are showing as dominant loading, whereas number of doctor strengths ($0.68)$, number of para-medical staff strengths ($0.476)$ and number of beds (-0.385) are showing negative loading. The variance explained in PC2 is $71.94 \%$, which signals the reality (see Table 4). Clearly, health and transport facilities are poor in condition and thereby, require further development.

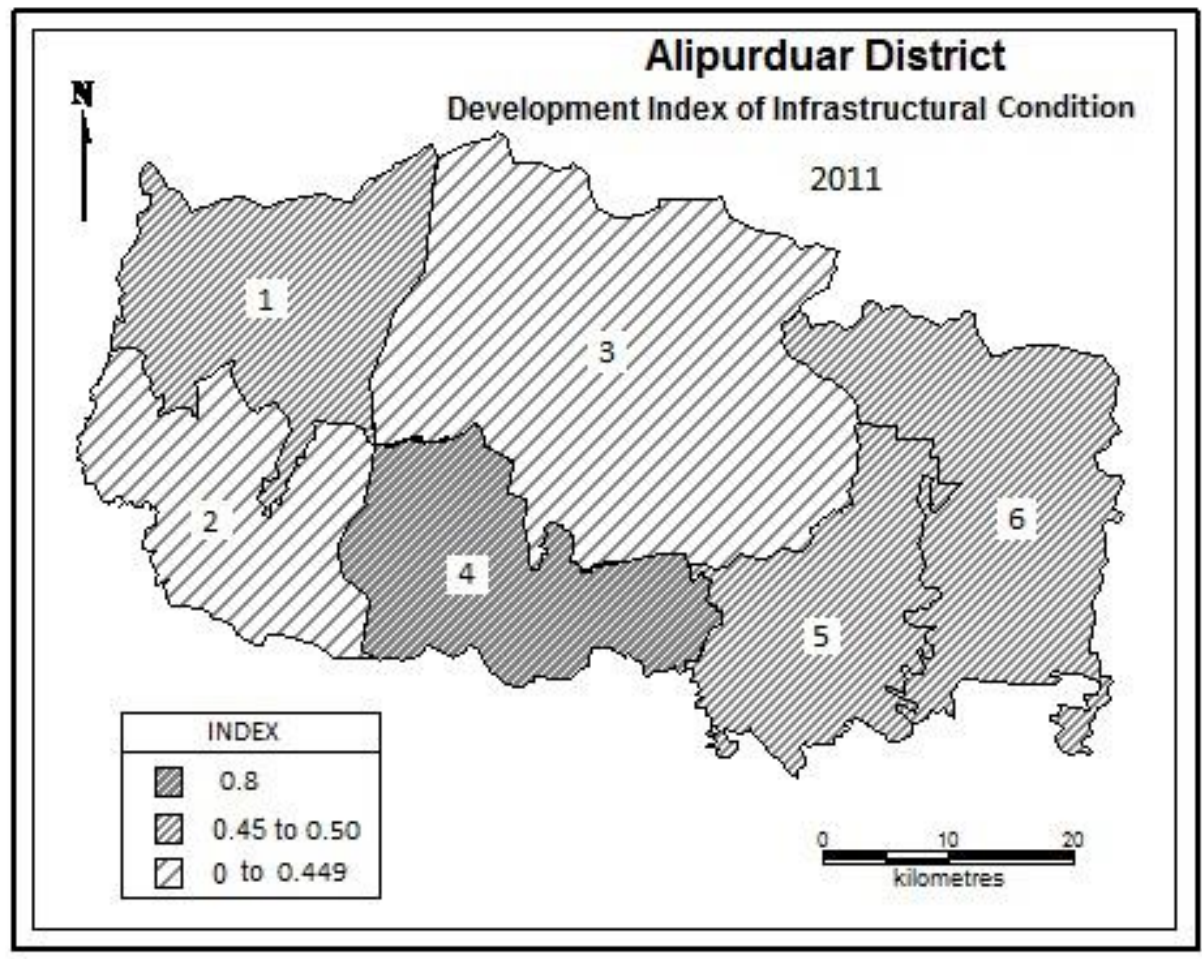

Figure 4 (Source: Authors' Calculation)

In order to understand the level of disparity in term of overall development of six blocks, Prince Score 1 and Prince Score 2 have been calculated from PC1 and PC2. Figure 5 shows clustering of level of development of six blocks within the district. As far as the population pressure is concerned, Alipurduar-I, Falakata and
Kumargram blocks are in better position. The quadrantile position (+,-) of Alipurduar-II, Madarihat-Birpara, and Kalchini indicates less development, therefore, they require further betterment of socio-economic and infrastructure conditions (see Figure 5). 
Table 3: Correlation Matrix

\begin{tabular}{|c|c|c|c|c|c|c|c|c|c|c|c|c|c|c|c|c|c|c|}
\hline & $X I$ & $X 2$ & $X 3$ & $X 4$ & X5 & X6 & $X 7$ & $X 8$ & $X 9$ & XIO & $X I 1$ & $\mathrm{X} 12$ & $X 13$ & $X I 4$ & XI5 & $X 16$ & $X 17$ & $X 18$ \\
\hline$X I$ & 1.000 & -.413 & .152 & .155 & -.146 & -.455 & -.233 & -.109 & .034 & .512 & .710 & .737 & .152 & -.549 & -302 & -.609 & -.734 & 636 \\
\hline$X 2$ & & 1.000 & .782 & .731 & .705 & -.410 & .217 & .375 & 439 & -.373 & -.079 & -.060 & .566 & .858 & -501 & -.002 & -.238 & -.144 \\
\hline X3 & & & 1000 & .988 & 769 & -.680 & .274 & 284 & .757 & -.032 & .386 & .284 & .866 & .611 & -.834 & -.165 & -.722 & .378 \\
\hline X4 & & & & 1.000 & .775 & -.594 & .352 & 248 & .839 & -.020 & .402 & 291 & .927 & .624 & -.892 & -.085 & -.705 & .420 \\
\hline$X 5$ & & & & & 1000 & -.291 & .771 & -.291 & 641 & -.595 & -.229 & -171 & .795 & .516 & -.657 & 391 & -.227 & .520 \\
\hline X6 & & & & & & 1000 & .302 & -379 & -.279 & -.377 & -.548 & -280 & -.297 & -.021 & 301 & .588 & .814 & -.309 \\
\hline X7 & & & & & & & 1.000 & -.682 & .505 & -.707 & -.494 & -.353 & .593 & .249 & -436 & .795 & .218 & .553 \\
\hline$X 8$ & & & & & & & & 1000 & .151 & 607 & .570 & .296 & .010 & 471 & -.093 & -.555 & -.368 & -.613 \\
\hline$X 9$ & & & & & & & & & 1.000 & .097 & .348 & .060 & 893 & .526 & -.793 & .276 & -.479 & .434 \\
\hline$X 10$ & & & & & & & & & & 1000 & .843 & 438 & -.146 & -290 & .041 & -.592 & -.530 & -.083 \\
\hline$X 11$ & & & & & & & & & & & 1.000 & .778 & .300 & -.037 & -.454 & -.717 & -.858 & .183 \\
\hline$X 12$ & & & & & & & & & & & & 1000 & .287 & .003 & -.530 & -.761 & -.708 & .186 \\
\hline$X 13$ & & & & & & & & & & & & & 1000 & .587 & -.962 & .143 & -557 & .538 \\
\hline$X 14$ & & & & & & & & & & & & & & 1.000 & -.554 & .146 & -.064 & -.338 \\
\hline$X 15$ & & & & & & & & & & & & & & & 1000 & .071 & 657 & -494 \\
\hline$X 16$ & & & & & & & & & & & & & & & & 1000 & .659 & .125 \\
\hline$X 17$ & & & & & & & & & & & & & & & & & 1000 & -.471 \\
\hline$X 18$ & & & & & & & & & & & & & & & & & & 1000 \\
\hline
\end{tabular}

\section{Source: Authors' Calculation}

Table 4: Extraction of Principal Components with Cumulative Percentage of Variance and Eigen Value

\begin{tabular}{|c|c|c|c|c|c|c|c|c|c|c|c|c|c|c|c|c|c|c|}
\hline Variables & $\mathrm{X} 1$ & $\mathrm{X} 2$ & $\mathrm{X} 3$ & $\mathrm{X} 4$ & $\mathrm{X} 5$ & $\mathrm{X} 6$ & $\mathrm{X} 7$ & $\mathrm{X} 8$ & $\mathrm{Xg}$ & $\mathrm{X} 10$ & $\mathrm{X} 11$ & $\mathrm{X} 12$ & $\mathrm{X} 13$ & $\mathrm{X} 14$ & $\mathrm{X} 15$ & $\mathrm{X} 16$ & $\mathrm{X} 17$ & $\mathrm{X} 18$ \\
\hline $\begin{array}{c}\text { PC1 } \\
(43.04 \%) \\
\text { Eigen } \\
\text { Value: } \\
3.169 \\
\end{array}$ & 0.137 & 0.606 & 0.765 & 0.772 & 0.729 & -0.61 & 0.671 & 0.545 & 0.66 & 0.559 & 0.685 & 0.555 & 0.739 & 0.571 & 0.735 & 0.59 & 0.768 & 0.57 \\
\hline $\begin{array}{c}\text { PC2 } \\
(71.94 \%) \\
\text { Eigen } \\
\text { Value: } 2.26\end{array}$ & 0.625 & 0.517 & 0.571 & 0.576 & 0.494 & 0.398 & 0.471 & 0.508 & 0.5 & 0.617 & 0.587 & 0.549 & 0.576 & 0.548 & 0.496 & -0.68 & 0.476 & 0.385 \\
\hline
\end{tabular}

\section{Source: Authors' Calculation}


Figure 5: Inter-block disparity in Alipurduar District using Quadrant Positional Analysis

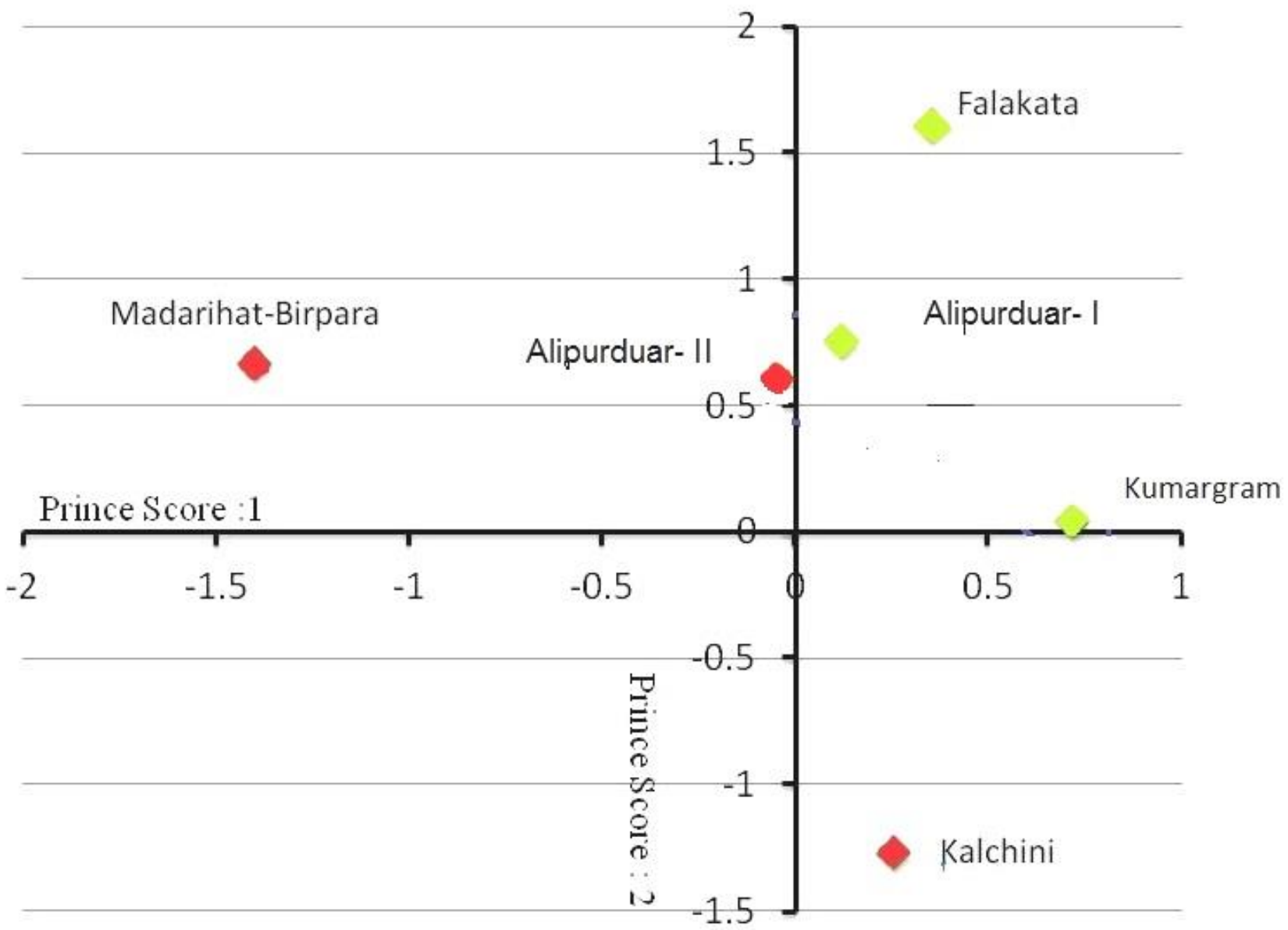

\section{Source: Authors' calculation}

\section{Concluding Remarks}

Development is a multi-faceted phenomenon which a society or a region achieves through its evolution process, and it has spatio-temporal dimension. In the present study, 18 indicators are taken under consideration according to the theme of the work. The youngest district, Alipurduar has been created to facilitate administrative works more easily and to provide better facilities to the people of the area. Therefore, the present state of imbalance within the district needs to look more carefully and it is a challenge to the respective administrative authority for formulating the diagnostic plan to achieve balanced regional development as well as to fulfil the aspirations of the local people.

\section{References}

About Alipurduar District, Available at: http://www.alipurduar.org/ (accessed 02/08/2015 at $13.35 \mathrm{hrs}$ )

Adhyapok, P.K. and A. R. Ahmed (2012). Disparity of Infrastructure in Assam: An InterDistrict Study, Indian Journal of Regional Science, XXXXIV (2), pp.118-121

Ahluwalia, M. S. (2000). Economic Performance of States in Post-Reforms Period, Economic \& Political Weekly, XXXV (19), pp.1637-1648 
Ahluwalia, M. S. (2001). Economic Performance of the States in the Post Reform Period, Ch. 28 in "Indian Economy since Independence" ed. Yuma Kampala Academic Foundation, New Delhi

Alipurduar a new district on June 25 (2014, June 21). The Times of India, Available at: http://timesofindia.indiatimes.com/city/kolkata /Alipurduar-a-new-district-on-June25/articleshow/36916065.cms (accessed $05 / 08 / 2015$ at $16.08 \mathrm{hrs}$ )

Census of India: 2011, Office of the Registrar General and Census Commission, India, New Delhi, Available at: http://censusindia.gov.in (accessed 25/08/2015 at $11.08 \mathrm{hrs}$ )

Chakraborty, A. (2009). Some Normatively Relevant Aspects of Inter-state and Intra-state Disparities, Economic \& Political Weekly, XLIV (26 \& 27), pp.179-184

Chandrasekhar, C.P. and J. Ghosh (2003). Per Capita Income Growth in the States, Business Line (The Hindu), August 12

Chandrasekhar, S. (2011). Workers Commuting Between the Rural and Urban: Estimates from NSSO Data, Economic and Political Weekly, Nov. 12, XLVI (46), pp. 22-25

Dadibhavi R.V. and S.T. Bagalkoti (1994). InterState Disparities in Health Status in India, Yojana, 38(23), pp.17-21

Das, S. K. and A. Barua (1996). Regional Inequalities, Economic Growth and Liberalisation: A Study of the Indian Economy, The Journal of Development Studies, 32 (3), pp. 364-390

District Statistical Handbook (2008). Jalpaiguri Agriculture \& Allied, Bureau of Applied Economics \& Statistics, Government of West Bengal, Silpabarta Printing Press, Kolkata

Drèze J. and Sen, A. (1995). Economic Development and Social Opportunity, Oxford University Press, Delhi (ISBN 10: 0198295286/ ISBN 13: 9780198295280)

Gruning, J.F. (1911). East Bengal and Assam District Gazetteers: Jalpaiguri, N.L. Publishers, Siliguri
Kumar, S. (2009). Inter-Region and Inter District Disparities in Agricultural Development: A study of Uttar Pradesh, Indian Journal of Regional Science, 41(1), pp.22-36

Kutscherauer. A, H. Fachinelli, M. Hučka, K. Skokan, J. Sucháček, P. Tománek, and P. Tuleja (2001). Regional Disparity: Disparities in Country Regional Development: Concept, Theory, Identification and Assessment, VŠBTechnical University of Ostrava. Retrieved from http://disparity.vsb.cz/edice_cd/cd11_regdis_ mono_angl/pdf/Regional\%20disparities.pdf

Mitra, A. (1965). Levels of Regional

Development in India, Census of India, Vol. I, Part I-A

Radhakrishna, R. and Rao, K.H. (2006). Poverty, Unemployment and Public Intervention. India's Social Development Report, New Delhi: Oxford University Press, pp.1-17

Raj, K. N. (1990). Bridging the Rural-Urban Gap, Economic and Political Weekly, XXV (1), pp. 25 $-27$

Report on Comparative Backwardness of North Bengal Region (2002). Planning Commission, Government of India, Institute of Applied Manpower Research, New Delhi

Sen, P.K. (2001). Geographical Perspective of the Rural Socio-Economic Inequality in West Bengal, Environment and Development (Ed.), The Geographical Society of India, Kolkata Shaban, A. (2002). Growth and Disparities of Income across Indian states, Man and Development, 24(1-4), pp.31-47

Shaban, A. (2006). Regional Structures, Growth and Convergence of Income in Maharashtra, Economic and Political Weekly, XLI (18), pp.1803-1815

Shastri, S. (1988). Regional Disparities in Economic Development of Rajasthan (1961-84), Indian Journal of Regional Science, 20(1), pp.1128

Shetty, S.L. (2003). Growth of SDP and Structural Changes in State Economies, Interstate Comparison, Economic and Political Weekly, 38(49), pp.5189-5200 
Shive, A.K. (1991). UNDP's Human

Development Index: A Computation for Indian

State, Economic and Political Weekly, 26(41),

pp. 2343-2345

\section{Acknowledgements}

We would like to acknowledge the anonymous reviewers for their valuable comments during preparation of the present work. 